\title{
Pengaruh Employee Stock Ownership Program Terhadap Average Abnormal Return Perusahaan Perbankan
}

\author{
Agung Suprayogi ${ }^{1} \&$ Abdul Basyith ${ }^{1}$ \\ ${ }^{1}$ Universitas Bina Darma \\ ${ }^{1}$ Universitas Muhammadiyah Palembang \\ Email: agungyogi49@gmail.com
}

\begin{abstract}
This research was conducted to see the effect of the implementation of the Employee Stock Ownership Program on average abnormal returns of banking companies before and after applying ESOP and trading volume. The aim is to find out the difference in average abnormal return before and after applying the ESOP. The variable used in this study is average abnormal return. The period of this research event is 20 days, 10 days, 5 days and 1 day which are divided before and days after the date of application. This study examines banking companies that apply the Employee Stock Ownership Program listed on the Indonesia Stock Exchange so that data is obtained from trading in the company's stock price. The sampling criteria used a purposive sampling method in order to obtain 9 samples. The hypothesis method used in the normally distributed data is Paired Samples T-test. The result is that all average abnormal return periods both on the first and the last date of the ESOP application have a significant value $>0.05$, which means that the entire event period of the variable is proven to have no significant difference both before and after the banking company applies the Employee Stock Ownership Program.
\end{abstract}

Keywords: Employee Stock Ownership Program, Average Abnormal Return, Agency Theory.

\section{Pendahuluan}

Employee Stock Option Program memberikan peluang bagi karyawan untuk memiliki sebagian saham perusahaan ditempat mereka bekerja pada periode tertentu dimasa mendatang dengan harga yang telah disetujui saat program ESOP diberikan (Triana, 2013). Employee Stock Option Program sangat bermanfaat bagi para karyawan, dimana para karyawan akan termotivasi untuk meningkatkan porsi saham yang dimilikinya dengan meningkatkan kompetensi dan kinerja untuk jangka waktu yang panjang (Fidhayanti, S.K., \& Dewi, 2012).

Penerapan Employee Stock Option Program (ESOP) diharapkan menjadi salah satu cara yang digunakan oleh perusahaan untuk menarik minat karyawan, sebab seluruh karyawan memiliki kesempatan dan berhak untuk mempunyai saham perusahaan ditempat mereka bekerja. Kesempatan yang diberikan perusahaan kepada karyawan untuk memiliki saham akan membuat karyawan mempunyai rasa memiliki perusahaan. Sehingga tujuan dari program kepemilikan saham karyawan yaitu memotivasi karyawan untuk ikut dalam memajukan perusahaan serta komitmen dan produktivitas karyawan akan meningkat (Wiratma, Tomi dan Kristanto, 2010). Employee Stock Ownership Program yang diterapkan oleh perusahaan diharapkan memiliki karyawan yang kinerjanya lebih efektif dan efesien, sehingga mampu menghasilkan kinerja keuangan yang lebih baik dengan tingkat laba yang tinggi. Sementara perusahaan yang tidak menerapkan ESOP para karyawannya hanya akan bekerja demi hak sebagai pegawai yaitu sekedar mendapatkan gaji tanpa ada motivasi lain.

Kebijakan yang dikeluarkan merupakan informasi bagi investor untuk menilai kinerja perusahaan. Kebijakan tersebut dikeluarkan melalui pengumuman kepada investor yang dapat memberikan sinyal positif bagi investor ketika kebijakan tersebut dianggap sebagai tindakan

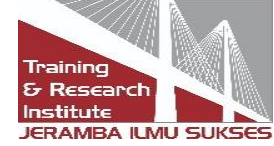


yang menguntungkan dan meningkatkan nilai perusahaan atau disebut dengan berita baik (good news), tetapi juga dapat diartikan sebagai sinyal negatif ketika dianggap mengurangi pendapatan yang akan diterima perusahaan atas investasi yang akan dan telah ditanamnya atau disebut dengan berita buruk (bad news). Kebijakan tersebut menjadi informasi paling relevan di pasar modal.

Perusahaan perbankan yang menerapkan employee stock ownership program (ESOP) dari tahun 2004 hingga tahun 2018 relatif berfluktuatif. Hal ini terjadi karena perusahaan perbankan menerapkan program tersebut tidak dilakukan setiap tahunnya bahkan hanya dilakukan dalam kurun waktu yang relatif singkat. Jika penerapan employee stock ownership program (ESOP) sesuai dengan ekspektasi awal tujuan penerapan maka perusahaan tersebut akan menerapkannya secara berkelanjutan. Bank Tabungan Pensiunan Nasional (Persero) Tbk menerapkan employee stock ownership program (ESOP) pada 31 Mei 2018, 1 hari setelah program tersebut diterapkan harga saham masih sama seperti pada saat hari penerapan, di dua hari berikutnya harga saham mengalami penurunan akibat dari penerapan employee stock ownership program (ESOP) hal tersebut mengindikasikan bahwa program ini tidak menjamin terjadinya peningkatan produktivitas.

Penelitian ini bertujuan untuk mengetahui bagaimana nilai mean pada average abnormal return (AAR) pada tanggal pembukaan penerapan dan tanggal penutupan perusahaan sektor perbankan yang menerapkan ESOP yang listing di BEI periode 2003-2018 terhadap volume perdagangan dan apakah terdapat perbedaan signifikan average abnormal return sebelum dan sesudah pelaksanaan ESOP pada perusahaan sektor perbankan yang listing di BEI periode 2003-2018.

\section{Tinjauan Literatur}

Teori agensi adalah sebuah teori yang menjelaskan adanya konflik antara manajemen dan pemegang saham .Hubungan keagenan dapat menimbulkan masalah ketika pihak-pihak yang bersangkutan di dalamnya memiliki kepentingan dan tujuan yang berbeda. Pemegang saham berharap bahwa mereka bisa mendapatkan keuntungan sebanyak-banyaknya, sedangkan manajer menginginkan peningkatan kesejahteraan bagi para manajer sendiri. Hal seperti inilah yang menyebabkan adanya konflik kepentingan antara pemegang saham dan manajer. Biasanya penyebab konflik diantara mereka salah satu faktornya disebabkan mengenai pembuatan keputusan yang berkaitan dengan aktivitas pendanaan (Nuswandari, 2013).

Employee Stock Option Program (ESOP) merupakan program manajemen sumber daya manusia berupa program kepemilikan saham karyawan dalam perusahaan dimana tempat karyawan tersebut bekerja (Bapepam, 2002).

Pasar modal adalah tempat terjadinya transaksi asset keuangan jangka panjang atau long-term fiancial assets. Jenis suat berharga yang diperjualbelikan dipasar modal memiliki jatuh tempo lebih dari satu tahun. Pasar modal memungkinkan terpenuhinya kebutuhan dana jangka panjang untuk investasi jangka panjang dalam bentuk bangunan, peralatan dan saranan produksi lainnya (Sartono, 2010).

Saham adalah salah satu bentuk efek yang diperdagangkan dalam pasar modal. Saham merupakan surat berharga sebagai tanda pemilikan atas perusahaan penerbitnya. Saham juga berarti sebagai tanda penyertaan atau pemilikan seorang atau badan dalam suatu perusahaan terbuka (Sunariyah, 2004).

\section{Abnormal Return}

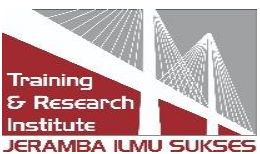


Abnormal return ( keuntungan tidak normal) adalah selisih antara tingkat keuntungan sebenarnya ( actual return) dengan tingkat keuntungan yang di ekspetasikan (expected return ) oleh investor (Jogiyanto Hartono, 2014).

\section{Actual Return}

Tingkat keuntungan sesungguhnya ( actual return ) adalah jumlah return yang terealisasi dan dapat dihitung melalui data historis. Return realisasi atau return sesungguhnya ini menjadi penting untuk diperhatikan sebagai pengukur kinerja perusahaan dan sebagai dasar penentuan return ekspektasian serta risiko yang akan terjadi di masa yang akan datang (Hartono A dan Wibowo A.J., 2014)

3. Expected Return

Return ekspektasian (expected return) merupakan return yang diharapkan oleh para investor di masa yang akan datang (Hartono, 2015).

Berkaitan dengan masalah yang akan dibahas dalam penelitian ini, diajukan hipotesis :

- $\mathrm{H}_{0}$ : Di duga tidak ada pengaruh ESOP terhadap average abnormal return di perusahaan sektor perbankan jika nilai $p$-value $>$ nilai $\alpha(0,05)$.

- $\mathrm{H}_{1}$ : Di duga ada pengaruh signifikan ESOP terhadap average abnormal return di perusahaan sektor perbankan jika nilai $p$-value $\leq$ nilai $\alpha(0,05)$.

\section{Metode Penelitian}

Penelitian ini menggunakan data sekunder yang didapat dari data harga saham perusahaan perbankan yang menerapkan employee stock ownership program yang terdaftar di Bursa Efek Indonesia. Sampel pada penelitian ini adalah perusahaan-perusahaan perbankan yang menerapkan employee stock ownership program periode 2003-2018. Variabel average abnormal return dilihat untuk mengetahui rata-rata tingkat pengembalian perusahaan perbankan yang menerapkan employee stock ownership program.

Teknik pengumpulan data yang digunakan dalam penelitian ini, yaitu dengan menggunakan studi dokumentasi. Studi dokumentasi dilakukan dengan mengumpulkan sumber-sumber data dokumenter seperti data historis harga saham perusahaan yang menjadi sampel penelitian.

Dalam rangka melakukan pemilahan alat analisis untuk penelitian, maka variabel operasional dalam penelitian ini adalah sebagai berikut :

Tabel 1. Variabel Operasional

\begin{tabular}{|c|c|c|c|}
\hline No & Nama Variabel & Definisi & Pengukuran \\
\hline 1. & Abnormal return & $\begin{array}{c}\text { selisih antara tingkat keuntungan } \\
\text { sebenarnya (actual return) dengan } \\
\text { tingkat keuntungan yang di } \\
\text { ekspetasikan (expected return) oleh } \\
\text { investor. }\end{array}$ & $\mathrm{AR}_{\mathrm{i}, \mathrm{t}}=\mathrm{R}_{\mathrm{i}, \mathrm{t}}-\mathrm{E}\left[\mathrm{R}_{\mathrm{i}, \mathrm{t}}\right]$ \\
\hline 2. & Actual return & $\begin{array}{c}\text { jumlah return yang terealisasi dan } \\
\text { dapat dihitung melalui data historis. }\end{array}$ & $\mathrm{R}_{\mathrm{i}, \mathrm{t}}=\frac{(P i, t)-(P i, t-1)}{P i, t-1}$ \\
\hline
\end{tabular}




\begin{tabular}{|c|c|c|c|}
\hline 3. & Expected return & $\begin{array}{c}\text { return yang diharapkan oleh para } \\
\text { investor di masa yang akan datang }\end{array}$ & $\mathrm{E}(\mathrm{R})_{, \mathrm{t}}=\frac{\sum R}{\mathrm{~N}}$ \\
\hline
\end{tabular}

Sumber:data diolah peneliti

Teknik analisis data adalah teknik yang digunakan untuk mengolah data guna mendapat informasi yang mudah dibaca sehingga dapat di manfaatkan untuk menemukan solusi permasalahan Fauzi, Dencik, \& Asiati, 2019).

Metode Even Study adalah penelitian yang mengamati dampak dari pengumuman informasi terhadap harga sekuritas. Penelitian event study umumnya berkaitan dengan seberapa cepat suatu informasi yang masuk ke pasar dapat tercermin pada harga saham (Jogiyanto Hartono, 2010). Dalam hal ini peristiwa yang diamati adalah penerapan employee stock ownership program. Adapun tahap - tahap event study adalah sebagai berikut:

a. Identifikasi Peristiwa

Penelitian ini menggunakan peristiwa penerapan employee stock ownership program 2003 $-2018$.

b. Mengidentifikasi Peristiwa dan Tahun Terjadinya Peristiwa

Tahap ini melakukan penentuan populasi, sampel dan pencarian data yang diperlukan seperti tahun sebelum dan sesudah penerapan employee stock ownership program perusahaan perbankan di Bursa Efek Indonesia.

c. Menentukan Event Windows

Event windows di bagi menjadi tiga yakni periode sebelum penerapan employee stock ownership program ( pre event), tanggal penerapan employee stock ownership program (event date) dan periode setelah penerapan employee stock ownership program (post event). Total periode uji adalah 1 hari, 5 hari, 10 hari dan 20 hari.

d. Menentukan Average Abnormal Return

Tahap penghitungan average abnormal return terdiri dari tiga yakni penghitungan return realisasian, return ekspektasi dan abnormal return

e. Analisis

Tahap ini memuat analisis deskriptif untuk mengetahui gambaran atau karakteristik data penelitian yaitu perusahaan yang menerapkan employee stock ownership program di Bursa Efek Indonesia.

f. Uji Normalitas

Pengujian normalitas data penelitian ini menggunakan uji kolmogorov - smirnov untuk mengetahui kelayakan data yang mendukung penelitian.

g. Uji Hipotesis

Untuk menguji hipotesis yang telah diajukan dan menganalisis hasil pengujian hipotesis dalam penelitian ini digunakan pengujian statistik. Untuk uji hipotesis peneliti menggunakan uji Paired sample T-test.

h. Kesimpulan

Peneliti menarik kesimpulan berdasarkan hasil uji hipotesis yang telah dilakukan. 


\section{Hasil dan Pembahasan}

\subsection{Uji Normalitas}

Uji normalitas digunakan untuk menganalisis data penelitian berdistribusi normal atau tidak berdistribusi normal. Pengujian ini menggunakan uji kolmogrov smirnov. Hasil dari uji normalitas ini akan digunakan untuk penentuan uji analisis selanjutnya, jika berdistribusi normal maka uji analisis yang digunakan adalah Paired Sample T-Test sedangkan jika tidak berdistribusi normal maka uji analisis yang digunakan adalah Wilcoxon Signed Rank Test.

Tabel 2. Hasil Uji Normalitas

\begin{tabular}{llll}
\hline Variabel & $P$-value & Syarat & Keterangan \\
\hline $\begin{array}{l}\text { AAR 5 Hari } \\
\text { Tanggal Pertama }\end{array}$ & .200 & .05 & Normal \\
$\begin{array}{l}\text { AAR 5 Hari } \\
\text { Tanggal Terakhir }\end{array}$ & .115 & .05 & Normal \\
$\begin{array}{l}\text { AAR 10 Hari } \\
\text { Tanggal Pertama }\end{array}$ & .200 & .05 & Normal \\
$\begin{array}{l}\text { AAR 10 Hari } \\
\text { Tanggal Terakhir }\end{array}$ & .008 & .05 & Tidak Normal \\
$\begin{array}{l}\text { AAR 20 Hari } \\
\text { Tanggal Pertama } \\
\text { AAR 20 Hari }\end{array}$ & .200 & .05 & Normal \\
Tanggal Terakhir & .200 & .05 & Normal \\
\hline
\end{tabular}

Uji normalitas diatas menunjukkan hasil yang berbeda dari masing-masing variabel. Variabel AAR tanggal pertama secara keseluruhan memiliki hasil $>0,05$ dan AAR tanggal terakhir menunjukkan hasil pengukuran $>0,05$ kecuali AAR hari ke 10 memiliki nilai $<0,05$. Ini menandakan bahwa kedua variabel tersebut berdistribusi normal dan uji analisis yang digunakan adalah Paired Sample T-Test namun AAR 10 hari Tanggal Terakhir tidak terdistribusi normal sehingga uji analisis menggunakan Wilcoxon Signed Rank Test.

\subsection{Uji Hipotesis}

Analisis ini digunakan untuk menguji hipotesis yang telah dibuat. Pengujian ini biasanya dilakukan untuk uji berpasangan dan saling berhubungan. Dalam hal ini, pengujian hipotesis berguna untuk menguji data penelitian yang dianalisis didasarkan perfoma sebelum dan sesudah menerapkan employee stock ownership program. Jika asymptotic significance $>0,05$ maka berdistribusi normal, sedangkan jika asymptotic significance $\leq 0,05$ maka tidak berdistribusi normal. Untuk data yang berdistribusi normal pengujian dilakukan dengan uji Paired Sample T-Test dan data yang tidak berdistribusi normal dengan uji Wilcoxon Signed Rank Test.

Tabel 3. Uji Hipotesis AAR Tanggal Pertama ESOP

\begin{tabular}{lllll}
\hline Variabel & $P$-value & Mean & Uji Analisis & Hasil \\
\hline
\end{tabular}




\begin{tabular}{lcccc}
\hline AAR 1 Hari & - & - & - & - \\
Sebelum \& & & & & \\
$\quad \begin{array}{l}\text { Sesudah } \\
\text { AAR 5 Hari }\end{array}$ & .720 & -.0042400 & Paired Sample T-test & $\begin{array}{c}\text { Tidak ada } \\
\text { perbedaan }\end{array}$ \\
$\begin{array}{l}\text { Sebelum \& } \\
\text { Sesudah }\end{array}$ & & & & \\
AAR 10 Hari & .827 & -.0014900 & Paired Sample T-test & $\begin{array}{c}\text { Tidak ada } \\
\text { perbedaan }\end{array}$ \\
$\begin{array}{l}\text { Sebelum \& } \\
\text { Sesudah }\end{array}$ & & & & Tidak ada \\
AAR 20 Hari & .593 & -.0023100 & Paired Sample T-test & $\begin{array}{c}\text { Tidar } \\
\text { perbedaan }\end{array}$ \\
$\begin{array}{l}\text { Sebelum \& } \\
\text { Sesudah }\end{array}$ & & & & \\
\hline
\end{tabular}

Hasil dari pengujian hipotesis pada tanggal pertama penerapan employee stock ownership program (ESOP) diatas menunjukan hasil variabel average abnormal return (AAR) 1 hari sebelum dan 1 hari sesudah tidak mempunyai $p$-value karena korelasi dan $\mathrm{t}$ tidak dapat dihitung karena jumlah kasus kurang dari atau sama dengan 1 . Untuk variabel average abnormal return (AAR) pada 5, 10, serta 20 hari sebelum dan sesudah penerapan employee stock ownership program (ESOP) mempunyai $p$-value sebesar 0,720 untuk 5 hari sebelum dan sesudah, pada 10 hari sebelum dan sesudah nilai $p$-value sebesar 0,827 , dan pada 20 hari sebelum dan sesudah memiliki $p$-value sebesar 0,593.

Karena nilai $p$-value lebih besar dari nilai signifikansi yaitu $0,05(0,720>0,05),(0,827>0,05)$ dan $(0,593>0,05)$ maka dapat disimpulkan Ho diterima, sehingga tidak terdapat perbedaan signifikan pada variabel average abnormal return (AAR) pada tanggal pertama dengan adanya penerapan employee stock ownership program. Sedangkan untuk nilai mean average abnormal return (AAR) pada tanggal pertama penerapan employee stock ownership program (ESOP) lebih cenderung negatif karena pada 5 hari sebelum dan sesudah yaitu -.0042400, untuk 10 hari sebelum dan sesudah sebesar -.0014900, dan pada 20 hari sebelum dan sesudah ialah -.0023100 yang berarti bahwa pada tanggal pertama penerapan employee stock ownership program (ESOP) menyebabkan nilai return negatif.

Tabel 4. Uji Hipotesis AAR Tanggal Terakhir ESOP

\begin{tabular}{|c|c|c|c|c|}
\hline Variabel & P-value & Mean & Uji Analisis & Hasil \\
\hline $\begin{array}{l}\text { AAR 1 Hari } \\
\text { Sebelum \& } \\
\text { Sesudah }\end{array}$ & - & - & - & - \\
\hline $\begin{array}{l}\text { AAR } 5 \text { Hari } \\
\text { Sebelum \& } \\
\text { Sesudah }\end{array}$ & .997 & .0000400 & Paired Sample T-test & $\begin{array}{l}\text { Tidak ada } \\
\text { perbedaan }\end{array}$ \\
\hline $\begin{array}{l}\text { AAR } 10 \text { Hari } \\
\text { Sebelum \& } \\
\text { Sesudah }\end{array}$ & 1.000 & .0000000 & $\begin{array}{c}\text { Wilcoxon Signed Rank } \\
\text { Test }\end{array}$ & $\begin{array}{l}\text { Tidak ada } \\
\text { perbedaan }\end{array}$ \\
\hline $\begin{array}{l}\text { AAR } 20 \text { Hari } \\
\text { Sebelum \& } \\
\text { Sesudah }\end{array}$ & .997 & -.0000150 & Paired Sample T-test & $\begin{array}{l}\text { Tidak ada } \\
\text { perbedaan }\end{array}$ \\
\hline
\end{tabular}


Hasil dari pengujian hipotesis pada tanggal terakhir penerapan employee stock ownership program (ESOP) diatas menunjukan hasil variabel average abnormal return (AAR) 1 hari sebelum dan 1 hari sesudah tidak mempunyai $p$-value sebab korelasi dan $t$ tidak dapat dihitung karena jumlah kasus kurang dari atau sama dengan 1. Untuk variabel average abnormal return (AAR) pada 5, 10, serta 20 hari sebelum dan sesudah penerapan employee stock ownership program (ESOP) mempunyai $p$-value sebesar 0,997 untuk 5 hari sebelum dan sesudah, pada 10 hari sebelum dan sesudah nilai $p$-value sebesar 1,000, dan pada 20 hari sebelum dan sesudah memiliki $p$-value sebesar 0,997 . Karena nilai $p$-value lebih besar dari nilai signifikansi yaitu $0,05(0,997>0,05),(1,0000>0,05)$ dan $(0,997>0,05)$ maka dapat disimpulkan Ho diterima, sehingga tidak terdapat perbedaan signifikan pada variabel average abnormal return (AAR) pada tanggal terakhir dengan adanya penerapan employee stock ownership program.

Nilai mean average abnormal return (AAR) pada 5 hari tanggal terakhir penerapan sebesar .0000400, untuk 10 hari pada tanggal terakhir penerapan yaitu .0000000 , dan saat 20 hari pada tanggal terakhir penerapan employee stock ownership program (ESOP) yaitu -.0000150 yang berarti bahwa mean average abnormal return (AAR) relatif berimbang antara negatif dan positif sehingga employee stock ownership program (ESOP) pada tanggal terakhir penerapan membuat return relatif berfluktuatif.

\section{Kesimpulan}

Berdasarkan hasil dari analisis data dan pembahasan mengenai pengaruh employee stock ownership program terhadap average abnormal return dan volume perdagangan maka dapat ditarik beberapa kesimpulan bahwa nilai mean pada variabel average abnormal return (AAR) pada tanggal pertama penerapan semua periode penelitan memiliki nilai mean negatif sehingga employee stock ownership program (ESOP) membuat return negatif sedangkan nilai mean pada variabel average abnormal return (AAR) pada tanggal terakhir penerapan employee stock ownership program (ESOP) pada semua periode penelitian memiliki nilai mean ada yang positif dan negatif bahkan ada yang bernilai 0 sehingga employee stock ownership program (ESOP) membuat return berfluktuatif. Untuk hasil uji hipotesis variabel average abnormal return (AAR) pada tanggal pertama setelah adanya penerapan employee stock ownership program semua periode memiliki nilai $>0,05$, sehingga Ho diterima. Hal ini mempunyai arti bahwa tidak ada perbedaan average abnormal return (AAR) pada tanggal pertama sebelum dan sesudah penerapan employee stock option program, sedangkan variabel average abnormal return (AAR) pada tanggal terakhir setelah adanya penerapan employee stock ownership semua periode memiliki nilai $>0,05$, sehingga Ho diterima. Hal ini mempunyai arti bahwa tidak ada perbedaan average abnormal return (AAR) di tanggal terakhir sebelum dan sesudah penerapan employee stock option program.

\section{Referensi}

Baltagi, B. (2008). Econometric analysis of panel data (John Wiley).

Bapepam. (2002). Studi tentang Penerapan ESOP Perusahaan Publik di Pasar Modal Indonesia. Departemen Keuangan Republik Indonesia.

Christiawan, Y. . dan J. T. (2007). Kepemilikan Manajerial: Kebijakan Hutang, Kinerja, dan Nilai Perusahaan. Akuntansi Dan Keuangan, 9.

Fauzi, F., Dencik, A. B., \& Asiati, D. I. (2019). Metodelogi Penelitian untuk Manajemen dan Akuntansi. Jakarta: Salemba Empat.

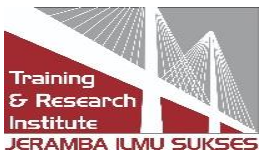


Fidhayanti, S.K., \& Dewi, N. H. . (2012). Analisis Nilai Perusahaan, Kinerja Perusahaan dan Kesempatan Bertumbuh Perusahaan Terhadap Return Saham pada Perusahaan Manufaktur yang Listing di BEI. The Indonesian Accountung Review.

Hardiningsih, P., \& Rachmawati, M. O. (2015). Determinan Kebijakan Hutang ( Dalam Agency Theory Dan Pecking Order Theory ) Determinants Of Debt Policy ( In Agency Theory And Pecking Order Theory ) ( Dalam Agency Theory Dan Pecking Order Theory ), (December).

Hartono, A., Fakultas, A., Universitas, E., Jaya, A., Wibowo, A. J., Pengajar, S., ... Yogyakarta, J. (2014). Pengaruh Employee Stock Ownership Program Terhadap Kinerja Perusahaan Publik Di Bursa Efek, 26(1), 85-91.

Hartono A dan Wibowo A.J. (2014). Pengaruh Employee Stock Program Terhadap Kinerja Perusahaan Publik di Bursa Efek Indonesia, 26.

Husnan, S. (2005). Dasar-Dasar Teori Portofolio dan Analisis Sekuritas (4th ed.). Yogyakarta: UPP STIM YKPN.

Jogiyanto Hartono. (2014). Teori Analisis dan Investasi (Sembilan). Yogyakarta: BPFEYOGYAKARTA.

Maharani, P. G. (2010). Analisis Perbandingan Kinerja Perusahaan Sebelum dan Sesudah Mengadakan Employee Stock Ownership Program (ESOP) dengan Perusahaan yang Tidak Mengadakan ESOP.

Ngambi, M. T., \& Oloume, F. (2013). Employee Share Ownership and Firm Performance: Evidence From a Sample of Cameroonian Firms. International Journal of Research In Social Sciences, 2(3), 48-55.

Nuswandari, C. (2013). Jurnal Dinamika Akuntansi, Keuangan, dan Perbankan, Determinan Struktur Modal dalam Perspektif Pecking Order Theory dan Agency Theory.

Nuzula, N. F., \& Najy, N. Y. (2017). Analisis Pengumuman Pelaksanaan Employee Stock Options Program Terhadap Average Abnormal Return Dan Volume Perdagangan Saham Di Indonesia ( Study Pada Perusahaan Yang Terdaftar Di Bei Periode Tahun 2011-2015 ), 50(2).

Rachmati, I. (2013). Pengaruh Penerapan Employee Stock Ownership Program (ESOP) Terhadap Peningkatan Kinerja Perusahaan Ditinjau Dari Perspektif Ekonomi Islam.

Sartono, A. (2010). Manajemen Keuangan Teori dan Aplikasi. Yogyakarta: BPFE.

Sugiyono. (2018). Metode Penelitian Kuantitatif. Bandung: Alfabeta.

Sunariyah. (2004). Pengantar Pengetahuan Pasar Modal. Yogyakarta: UPP AMP YKPN.

Triana, D. (2013). Pengaruh Program Opsi Saham Karyawan terhadap Kinerja Keuangan Perusahaan: Studi Empiris pada Bursa Efek Indonesia, Triana, D. 2013. Pengaruh Program Opsi Saham Karyawan terhadap Kinerja Keuangan Perusahaan: Studi Empiris pada Bursa Efek Indonesia, E-jurn, 7.

Wiratma, Tomi dan Kristanto, R. S. (2010). Analisis Pengaruh ESOP (Employee Stock Ownership Program) terhadap Kinerja Perusahaan di Bursa Efek Indonesia, 7.

Yahya, F. fauzi, Basyith, A., \& Antoni, D. (2018). STATISTIK. Depok: PT RAJAGRAFINDO PERSADA.

Yushita, A. N. (2010). Earnings Management dalam Hubungan Keagenan. Pendidikan 
Akuntansi Indonesia, VIII, 53-56.

www.idx.co.id

http://finance.yahoo.com

\section{Copyrights}

Copyright for this article is retained by the author(s), with first publication rights granted to the journal.

This is an open-access article distributed under the terms and conditions of the Creative Commons Attribution license (http://creativecommons.org/licenses/by/4.0/) 